\title{
DISABLED ANALYSIS OF CERAMIC PRODUCTS ON THE GLASS PROCESS USING THE SEVEN TOOLS METHOD (CASE STUDY: PT. NJMX SURABAYA
}

\author{
Yunia Dwie Nurcahyanie ${ }^{1}$, Titik Koesdijati ${ }^{2}$ \\ ${ }^{1,2}$ Industrial Engineering Department, Faculty of Industrial Technology \\ University of PGRI AdiBuana Surabaya \\ E-mail : yuniadwie@unipasby.ac.id
}

\begin{abstract}
In the production process of quality is very off at PT. NJMX, a company engaged in the manufacture of ceramics where the quality of a good ceramic surface does not have any disability is expected by consumers. This study aims To identify the disability of ceramic products by using the seven tools method on the glaze process, applying the seven tools method as an effective tool to improve productivity and product quality in the process of making ceramic diunit glaze. From the data processing, it can be known that the type of defect that has a high percentage obtained is the pinhole with the total average defect is 57 units, other causes are Dimpel 53 units, 50 glaze cracking, 48 lines and 45 units waves. Of the five types of defects the highest percentage is pinhole defect with a total percentage of $22.60 \%$, while for dimpel $20.90 \%$, cracked glaze $19.66 \%, 18.93$ and $18.93 \%$ waves. And obtained the average value of sigma 3.58 with $D P M O$ value of $13.553 \%$.
\end{abstract}

ABSTRACT
Keyword: Seven tools, Disability, Disability analysis

\section{Introduction}

firing and double firing with a variety of motifs, designs and sizes. Single firing is a type of ceramic used for walls while double firing is used for floors.

quality control system that is created and implemented. But until now the company has only reached 2250 units for the production of quality A. This research is focused on the Glaze process, the ceramic coating process plays an important role in the production process, because product defects often occur in this process. So that this study aims to identify defects in ceramic products to reduce defects in ceramic products (defects) using the method of repair that is the seven tools method. The use of the seven tools method will provide many benefits for the company. Some previous studies regarding product defect analysis that can be used as references in this study are as follows:

a. Analysis of improving the quality of ceramic products by using the Six Sigma method at CV. Glassmico tile Tulungagung, RonyPrabowo Vol.16 December 2, 2012 quality improvement to eliminate the root causes of failure and improve the quality of the process suppress the failure rate of 3.4 DPMO.

b. Improving the quality of ceramic products with a six sigma approach in the ceramic industry of Dinoyo - Malang, AnnisaKesy Garside Vol.6 No. August 1, 2007, p. 18 28 Application of the Six Sigma Method, Reducing failure modes based on the Highest RPN value in FMEA.

c. Evaluation of the implementation of quality control systems at PT. X, AmeyliaDewiseptiani, JurnalTitra Vol. 1 No. 1, Janurari 2013, pp. 33-40, making a process control system that focuses on the production stages of each machine, as well as the proposed improvements to sampling at each inspection carried out.

\section{Methodology \\ 2.1 Research design}

PT. NJMX Surabaya. Determining the objectives and benefits of further research data retrieval was carried out for 15 weeks of data processing using the seven tools method, namely check sheet, pareto diagram, fishbone 


\section{Tibuana}

Journal of applied Industrial Engineering-University of PGRI Adi Buana

diagrams, controlchart so as to obtain data on motifs on glaze units.

identifying defects of embossed ceramic type

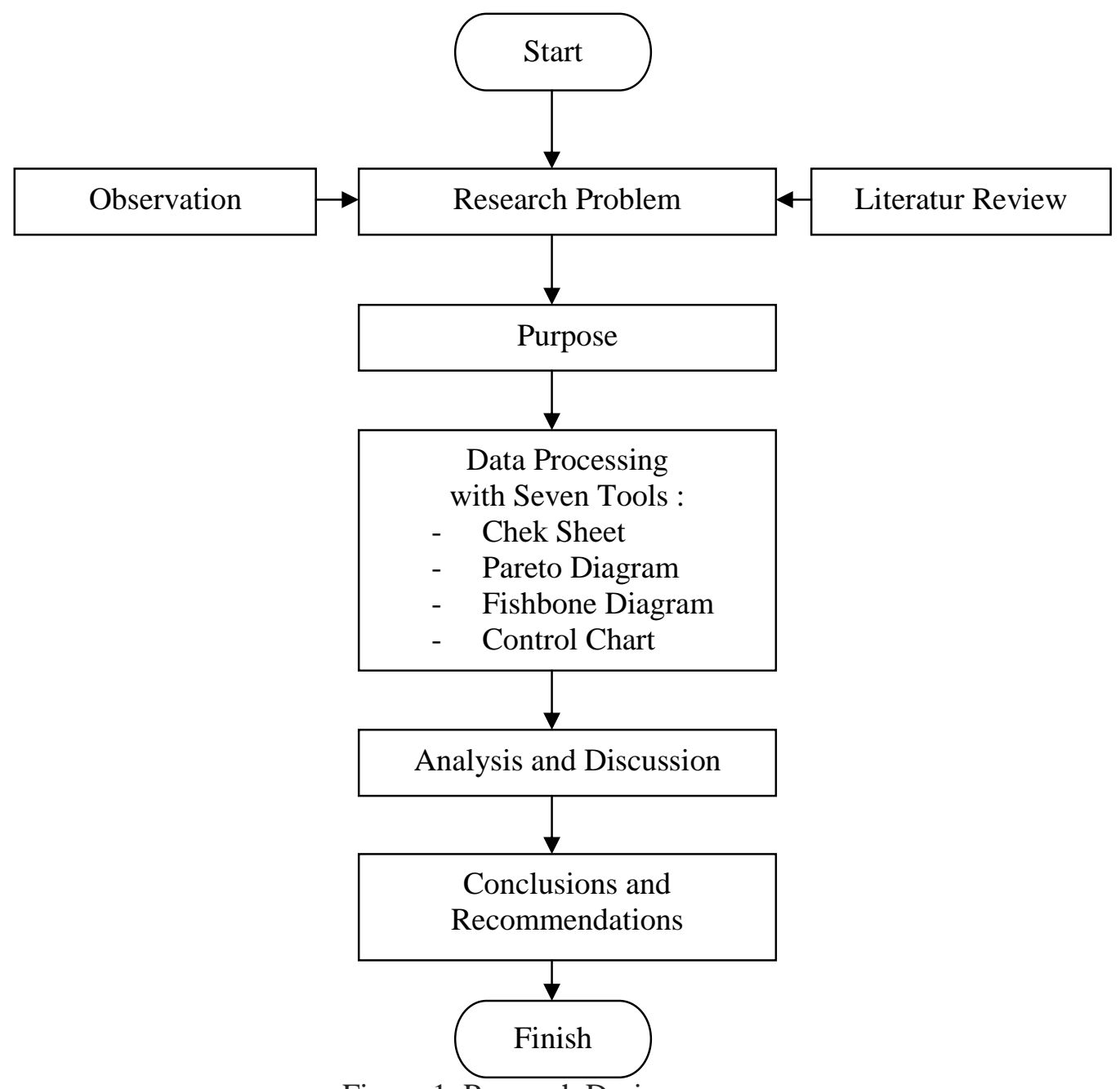

Figure 1. Research Design

\subsection{Variables}

The research variable is the object of research, or what is the focus of research (Arikunto, 2006: 118). The variables studied must be in accordance with the problems and objectives to be achieved in this study. In this study, two variables are as follows:
a. Disability quality of embossed ceramic products.
b. The seven tools method.

\subsection{Population and sample}

a. Population according to Ferdinand (2011) is a combination of all elements in the form of events, things or people who have similar characteristics to be the center of attention of a researcher because it is seen as a research universe. The population in this study is the quantity of embossed motifs of 2500 units, size $40 \times 40 \mathrm{~cm}$ in PT. NJMX Surabaya.

b. Understanding the sample according to Sugiyono (2010: 62) "The sample is the number or characteristics of the population for that sample taken from the population must be truly representative or representative of the entire population. The sample used in this study was a ceramic product of embossed motifs measuring $40 \times 40 \mathrm{~cm}$, glazed with 1270 units which had defects during the coating process.

\subsection{Data Collection Method}

The selection of the types of ceramics studied was because the production of ceramics from this company was a job order system (in accordance with customer orders) so that this 


\section{Tibuana}

Journal of applied Industrial Engineering-University of PGRI Adi Buana

month's production might be different from the following month, while this research focused on the type of ceramic emboss motif size of 40 $\mathrm{x} 40 \mathrm{~cm}$.

Based on the data that will be used in this study, data collection methods consist of: a. Obedience directly in the field for 15 weeks.

b. Company historical data in December 2016-March 2017, for the calculation of defect embossed ceramic motifs at the coating process stage, followed by glaze.

\section{Results and Discussion}

Table 1.

Production data for Glazed Ceramic Products Embossed motifs, Defect amount of ceramics Week 1-15 December 2016 to March 2017 (in Unit Units per Week)

\begin{tabular}{|c|c|c|c|c|c|c|c|}
\hline \multirow[b]{2}{*}{ Week } & \multirow[b]{2}{*}{ Production } & \multicolumn{5}{|c|}{ Type of defect } & \multirow{2}{*}{$\begin{array}{l}\text { Percentage } \\
\text { of defect }\end{array}$} \\
\hline & & $\begin{array}{c}\text { Needle } \\
\text { Hole }\end{array}$ & Striped & Wave & $\begin{array}{c}\text { Cracked } \\
\text { Glaze }\end{array}$ & Dimple & \\
\hline 1 & 13500 & 47 & 69 & 31 & 32 & 63 & 1,79 \\
\hline 2 & 13446 & 43 & 68 & 35 & 37 & 33 & 1,61 \\
\hline 3 & 13488 & 52 & 54 & 44 & 47 & 63 & 1,93 \\
\hline 4 & 13488 & 69 & 43 & 42 & 67 & 46 & 1,98 \\
\hline 5 & 13500 & 68 & 47 & 33 & 42 & 69 & 1,92 \\
\hline 6 & 13572 & 59 & 47 & 44 & 69 & 53 & 2,00 \\
\hline 7 & 13488 & 73 & 43 & 57 & 48 & 53 & 2,03 \\
\hline 8 & 13464 & 39 & 45 & 46 & 62 & 51 & 1,80 \\
\hline 9 & 13566 & 68 & 41 & 37 & 34 & 43 & 1,64 \\
\hline 10 & 13548 & 63 & 48 & 65 & 38 & 51 & 1,96 \\
\hline 11 & 13512 & 65 & 39 & 53 & 43 & 66 & 1,97 \\
\hline 12 & 13488 & 43 & 37 & 44 & 49 & 68 & 1,79 \\
\hline 13 & 13404 & 72 & 46 & 64 & 48 & 41 & 2,02 \\
\hline 14 & 13548 & 33 & 56 & 46 & 70 & 43 & 1,83 \\
\hline 15 & 13518 & 68 & 39 & 42 & 64 & 54 & 1,98 \\
\hline Total & 202530 & 862 & 722 & 683 & 750 & 797 & 28,25 \\
\hline Average & 13502 & 57,47 & 48,13 & 45,53 & 50,00 & 53,13 & 1,88 \\
\hline
\end{tabular}

Source : Data processed, 2017

\subsection{Data Processing}

Data processed from the observation table for 15 weeks to find out the percentage of product types rejected by the formula:

$$
\% \text { Defect } \quad=\frac{A \quad T \quad D D}{A \quad D}
$$

$\%$ Needle Hole $=\frac{5,4}{2} \times 100 \%$

$\%$ Dimpel $\quad=\frac{5,1}{2} \times 100 \%$

$$
=22,60 \%
$$$$
=20,90 \%
$$

$$
\begin{aligned}
\text { \% Cracked Glaze } & =\frac{5}{2} \times 100 \% \\
\% \text { Striped } & =\frac{4{ }^{1}}{2} \times 100 \% \\
& =19,66 \% \\
& =18,93 \%
\end{aligned}
$$




\section{Tibuana}

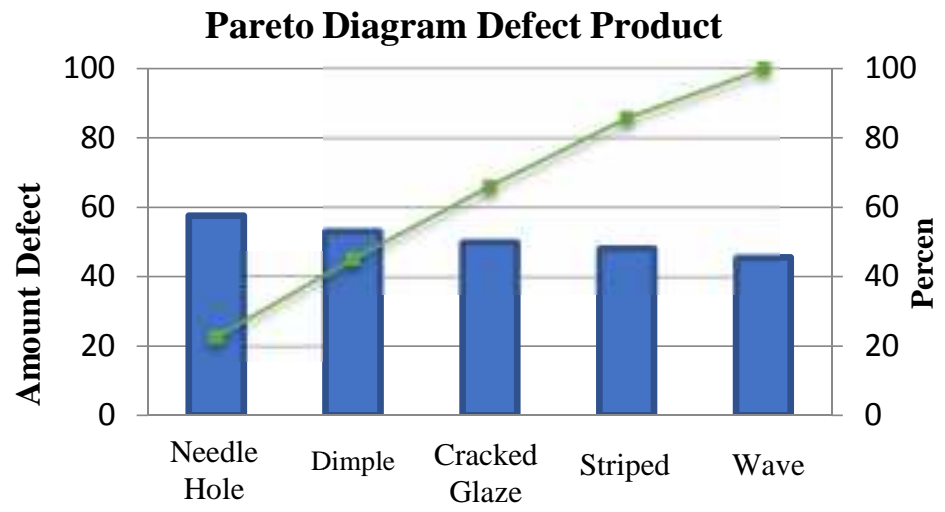

Figure 2. Percentage Type of Defect.

Units of Dimpel, 50 units of cracked glaze, 48 units of lines and 45 units of waves. Of the five types of defects, the highest percentage was pinhole defects with a total percentage of $22.60 \%$, while for dimpel $20.90 \%$, glaze cracks $19.66 \%$, striped 18.93 and waves
$17.91 \%$. Repairs can be done by focusing on the single biggest type of defect. This is because the type of defect is a problem of product quality control in the Glaze unit of PT. NJMX for the glaze coating process.

\subsection{Analysis Control ( $X$-Bar and $R$ chart)}

$$
\begin{aligned}
\mathrm{UCL} & =\mathrm{X}+\mathrm{A}_{2} . \mathrm{R} \\
& =50,8+(0,577.29) \\
& =50,8+16,733 \\
& =67,733
\end{aligned}
$$

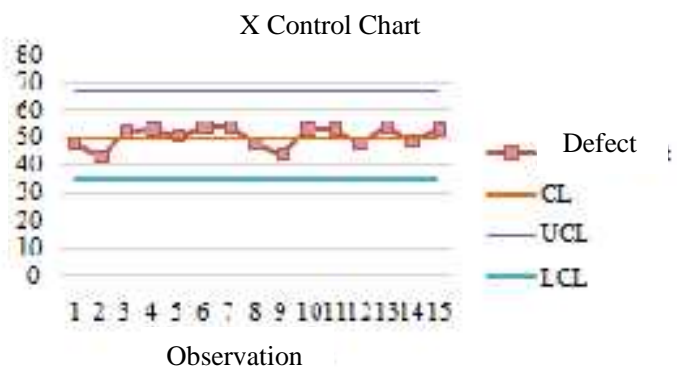

Figure 3. X Control Chart

$$
\begin{aligned}
\mathrm{CL}=\mathrm{X} & =50,8 \\
\mathrm{LCL} & =\mathrm{X}-\mathrm{A}_{2} . \mathrm{R} \mathrm{R} \\
& =50,8-\left(\begin{array}{ll}
0,577 & .29
\end{array}\right) \\
& =50,8-16,733 \\
& =35,22
\end{aligned}
$$

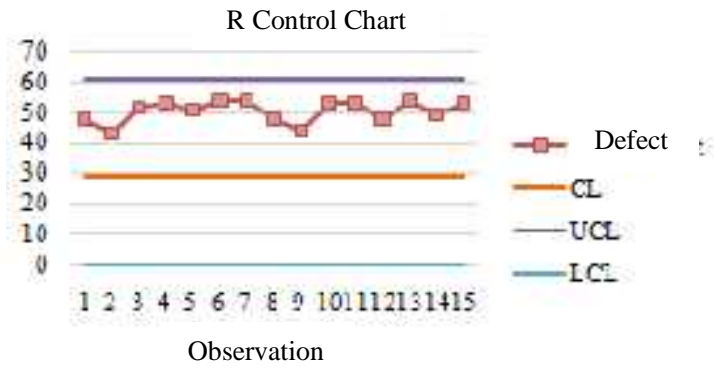

Figure 4. R Control Chart 


\section{Tibuana}

Journal of applied Industrial Engineering-University of PGRI Adi Buana

$$
\begin{aligned}
\mathrm{UCL} & =\mathrm{D}_{4} \cdot \mathrm{R} \\
& =2,114 \cdot 29 \\
& =61,309
\end{aligned}
$$

$$
\begin{aligned}
\mathrm{C}=\mathrm{R} & =29 \\
\mathrm{LC} & =\mathrm{D}_{3} . \mathrm{R} \\
& =0.29 \\
& =0
\end{aligned}
$$

\subsection{Stage Analysis of Cause and Effect Diagrams}

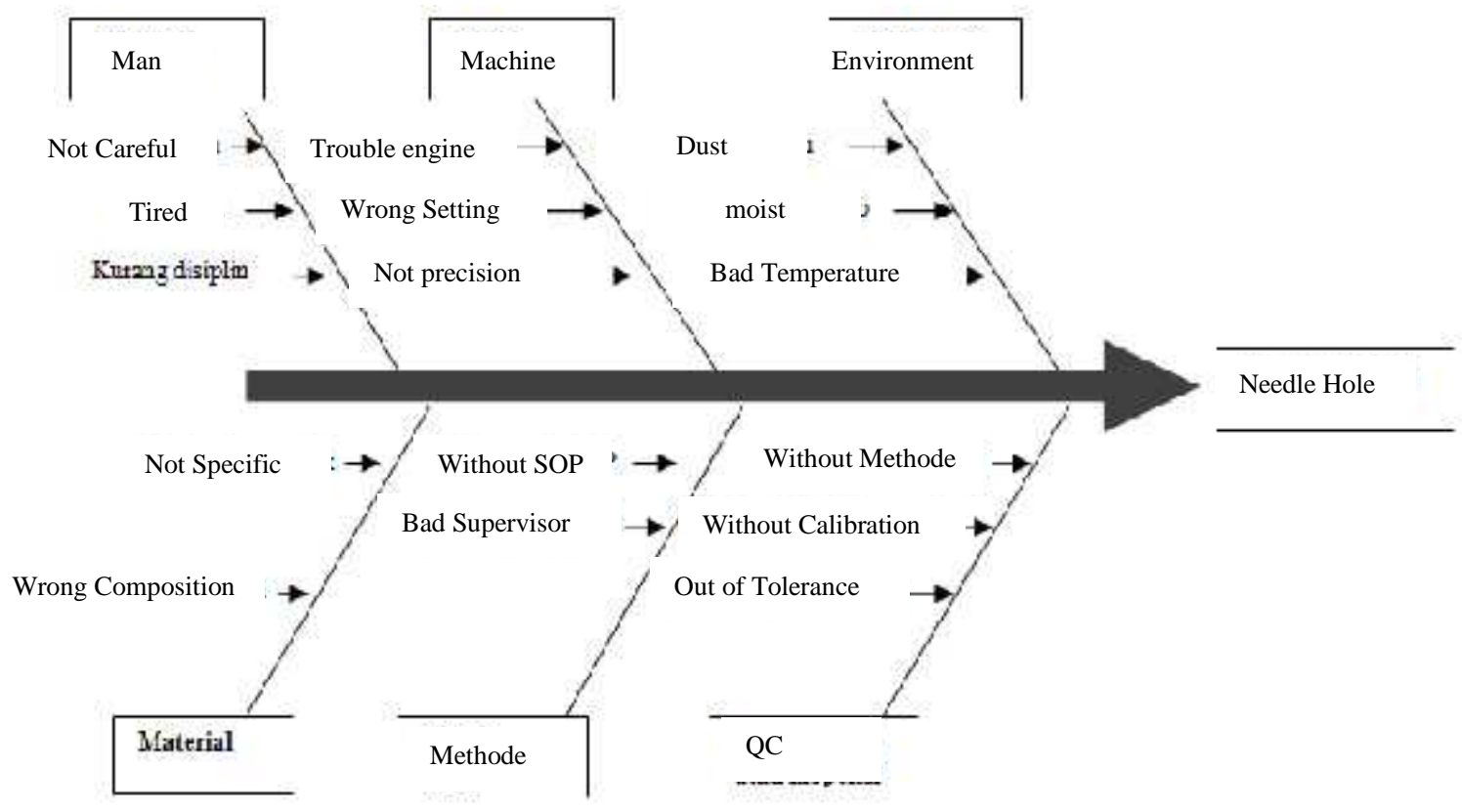

Figure 5. Fish Bone Diagram

\subsection{Stage of Measurement of Sigma and Defect Per Million Opportunities (DPMO)}

To measure the level of Sigma from the production of Glaze unit PT. NJMX steps are as follows:

\section{DPU (Defect Per Unit)}

DPU $=\frac{T \quad D}{T \quad P}$

DPU (Defect Per Unit) in first week

DPU $=\frac{2}{1}=0.017925926$
DPMO ( Defect Per Million Oportunities)

$\mathrm{DPMO}=\frac{T \quad D \quad P}{T \quad P} \times 1.000 .000$

DPMO (Defect Per Miliion Oportunities) first Week

DPMO $=\frac{2}{1} \times 1.000 .000=1792,592593$ 
Table 2. DPMO Keramik with Glasir

\begin{tabular}{|c|c|c|c|c|c|}
\hline Week & Total Reject & Total Product & DPU & DPMO & SIGMA \\
\hline DPU 1 & 242 & 13500 & 0,017925926 & 1792,5925 & 3,6 \\
\hline DPU 2 & 216 & 13446 & 0,016064257 & 1606,4257 & 3,64 \\
\hline DPU 3 & 260 & 13488 & 0,019276394 & 1927,6393 & 3,57 \\
\hline DPU 4 & 267 & 13448 & 0,019795374 & 1979,5373 & 3,56 \\
\hline DPU 5 & 259 & 13500 & 0,019185185 & 1918,5185 & 3,57 \\
\hline DPU 6 & 272 & 13572 & 0,020041261 & 2004,1261 & 3,55 \\
\hline DPU 7 & 274 & 13488 & 0,020314353 & 2031,4353 & 3,54 \\
\hline DPU 8 & 243 & 13464 & 0,018048128 & 1804,8128 & 3,59 \\
\hline DPU 9 & 223 & 13566 & 0,016438154 & 1643,8154 & 3,63 \\
\hline DPU 10 & 265 & 13548 & 0,019560083 & 1956,0082 & 3,56 \\
\hline DPU 11 & 266 & 13512 & 0,019686205 & 1968,6204 & 3,56 \\
\hline DPU 12 & 241 & 13488 & 0,017867734 & 1786,7734 & 3,61 \\
\hline DPU 13 & 271 & 13404 & 0,020217843 & 2021,7845 & 3,54 \\
\hline DPU 14 & 248 & 13548 & 0,018305285 & 1830,5284 & 3,59 \\
\hline \multirow[t]{3}{*}{ DPU 15} & 267 & 13518 & 0,019751443 & 1975,1442 & 3,56 \\
\hline & & & Total & 26272,6185 & 53,67 \\
\hline & & & Average & 1883,184185 & 3,53 \\
\hline
\end{tabular}

\subsection{Measure}

Measure is a measurement phase which is divided into two stages, namely the control diagram analysis phase and the measurement stage of the Sigma and Defect Per Million Opportunities (DPMO) levels. Data taken from PT. NJMX, which is quality control measured by the number of final products. Measurements were made with a control chart of production from December 2016 to March 2017. 1270 sample units used were embouse motif ceramics that had been coated with glaze that had become defective.

\subsection{Analyze}

Analize is the third stage to improve quality by identifying the cause of damage using pareto diagrams and cause and effect diagrams, based on table 3.1, the highest potential cause of disability is the pinhole with 57 units of total defects, the other causes include 53 units of Dimpel, Cracks glaze 50 units, striped 48 units and wave 45 units. Of the five types of defects, the highest percentage was pinhole defects with a total percentage of $22.60 \%$, while for dimpel $20.90 \%$, glaze cracks $19.66 \%$, striped 18.93 and waves $17.91 \%$.

\subsection{Improve}

a. Analysis results.

1. Machines are the main cause of defects in ceramic products due to lack of regular maintenance.
2. Lack of understanding of work procedures for the stages of the process.

b. Corrective action taken.

1. The need for repairs that are considered important include all machine instruments that are in the glaze maintenance unit on a regular basis, the availability of spare parts at the time of the replacement process.

2. The need for continuous socialization of SOP (Standard Operating Procedure) for employees and trainin assistance on a regular basis.

\subsection{Control}

It is the final analysis phase to complete all research and convey the results of the improvement process to up management. Ensure that everyone working is trained to carry out repair procedures.

a. All workers are enticed by the glaze to work based on the instructions of the company leadership.

b. Periodic maintenance of tools, machinery factors that are considered important in supporting the maximum production process in the glaze unit.

c. Total defect products in one month period are listed in the report book so that it can be analyzed by the work leadership.

d. All workers have an awareness of following disciplinary work 
procedures from any aspect while working.

e. Always strive to achieve the best quality in the production process by making a daily report recording the type of defect. By glaze unit workers at the time of production.

f. Supervision in the production process of glaze and engobe materials for all glaze unit employees to produce maximum quality.

g. Coordination between employees when transferring shifts work together to improve work quality

h. The need for socialization to all employees of glaze units will be a good and correct understanding of SOP (Standard Operating Procedure) work.

i. There must be periodic trainning for all glaze unit employees so that procedures while working can be stable.

j. Conducting deliberations every week for employees and leaders, solving problems that arise during the production process and finding solutions to solutions together every week can alternate between shifts.

\section{DAFTAR PUSTAKA}

Ariani, 2003. Manajemen Kualitas, Pendekatan Sisi Kualitatif. Penerbit PT Ghalia Indonesia, Jakarta

Annisa Kesy Garside, 2007 Peningkatan Kualitas Produk Keramik Dengan Pendekatan Six Sigma Pada Industri Keramik Dinoyo - Malang

Augusty Ferdinand, 2011,Structural Equation Modelling Dalam Penelitian Manajemen,BP, Undip, Semarang.

Arikunto, Suharsimi. 2005. Manajemen Penelitian.Cetakan Ketujuh, Penerbit Rineka Cipta, Jakarta.

Arikunto, Suharsimi, 2006, Prosedur Penelitian: Suatu Pendekatan Praktek, Edisi Revisi, PT, Rineka Cipta, Jakarta.

Budiarto, Samsul. 2010. Perbaikan Sistem Pengendalian Kualitas Dengan Menggunakan Metode Six Sigma. Jurnal

\section{Conclusions}

From the Pareto diagram used to identify the biggest defects that occur during the glaze coating stage, the glaze unit is PT. NJMX Surabaya has the highest percentage of the five types of defects. The main defect is the pinhole with a total average of 57 defects, other causes include Dimpel 53 units, Glaze cracks 50 units, Striped 48 units and 45 wave waves. Of the five types of defects, the highest percentage was pinhole defects with a total percentage of $22.60 \%$, while for dimpel $20.90 \%$, glaze cracks $19.66 \%$, striped 18.93 and waves $17.91 \%$. Based on the observation sheet (Check Sheet), it can be seen that the types of defects that often occur are defects due to pinholes with a total number of 862 units, 722 units of stripes, 683 units of waves, 750 units of glaze cracks and 797 units of Dimpel. Data obtained from observations for 15 weeks with an average production of 2250 units per day, with a total production of 202530 for 15 observations. Various kinds of improvement proposals and various ways for the company to reduce product defects are expected to further maximize the production process in the future.

Manejemen UNNUR Bandung, Vol 2, No 1

Bresee, J. S., et al.,2012. The Etiology of Severe Acute Gastroenteritis Among Adults Visiting Emergency Departments in the United States. The Journal of Infectious Disease. 205 : 1374-1381

Croasby ,1997Philip Crosby, 75, Developer Of the Zero-Defects Concept

Djaslim Saladin, Yevis Oesman, 2002, "Intisari Pemasaran dan Unsur Pemasaran",Penerbit : Lindakarya, Bandung

Effendi, H. 2003. Telaah Kualitas Air bagi Pengelolaan Sumber Daya dan Lingkungan Perairan. Cetakan Kelima. Yogjakarta : Kanisius.

Feigenbaum, M. J. (1978). "Quantitative Universality for a Class of Non-Linear Transformations". 


\section{Tibuana}

Journal of applied Industrial Engineering-University of PGRI Adi Buana

p-ISSN 2622-2027

$e$-ISSN 2622-2035

Kolter dan Amstrong (2001:346) Armstrong, Gary dan Philip Kotler.(2006) Marketing: An Introduction. Eight Edition. Prentice Hall.

Lupiyoadi, Rambat.(2001).Manajemen Pemasaran Jasa, SalembaEmpat, Jakarta.

Monreo, J.D, (2006) Analizing Value Stream, Quality vol.45,p.50

McCarthy, Jerome, E.; Perreault, William D, 2003. Dasar-dasar Pemasaran, Edisi kelima, alih Bahasa : Agus Darma. Jakarta : Erlangga.

Munawaroh. 2012. Panduan Memahami Metodologi Penelitian. Cetakan Pertama. PT.Intimedia.

Prawirohartono, Slamet, Sri Hidayati, Sains Biologi, Jakarta: PT Bumi Aksara, 2007.

Prawirosentono, Suyadi. 2002. Manajemen Sumber Daya Manusia: Kebijakan Kinerja

Karyawan. Edisi 1. Cetakan Kedelapan. BPFE. Yogyakarta

Rony Prabowo 2012 Analisis Peningkatan Kualitas Produk Keramik Dengan Menggunakan Metode Six Sigma DI CV. GLASSMICO TILE TULUNGAGUNG

Ratnaningtyas, D.D., Surendro, K., 2013. Information Quality ImprovementModel on Hospital Information System using Six Sigma. Journal ofprocedia technology, Vol. 9, pp. 1166-1172

Riduan. (2009). Dasar-Dasar Statistika. Bandung : Alfabeta

Susetyo, J; Winarni; Hartanto, C .2011. Aplikasi Six Sigma DMAIC Dan Kaizen Sebagai Metode Pengendalian Dan Perbaikan Kualitas produk.

Scherkenbach, Wiliam W., Deming's. (1991) Road to Improvement, SPC Press, Inc., Knoxville. Tennessee. 